\title{
Nyt websted om olie og gas - klik ind på www.geologi.dk/oliegas
}

Af geolog Ulla V. Hjuler, GeologiskNyt

En ny spændende webside om olie og gas er nu tilgængelig på nettet. Det er Nationalkomiteen for Geologi, der står bag initiativet med hjælp fra forskellige sponsorer.

I forbindelse med overrækkelsen af DONGs hæderslegat til professor John Korstgård, Aarhus Universitet, d. 22. april lanceredes et nyt og spændende websted om olie og gas. Det er Nationalkomiteen for Geologi, der står bag med økonomisk hjælp fra bl.a. DONGs jubilæumsfond. Også olieselskabet Denerco Oil og den højteknologiske danske software- og konsulentvirksomhed Ødegaard A/S har i foråret 2004 bidraget som sponsorer.

Flot og overskuelig opsætning

Siden er opbygget meget overskueligt med flotte og illustrative billeder. På forsiden kan man vælge mellem opslagene "Geologiske forudsætninger", "Olie og gas i Danmark" og "Efterforskningsmetoder". Endelig er der opslaget “Oversigten", hvor man kan se alle emnerne. De forskellige temaer er fremstillet yderst appetitligt med forklarende illustrationer og flotte fotos, og man kan sagtens læse om de enkelte emner hver for sig. Under "Geologiske forudsætninger" kan man fx vælge kildebjergarter, modenhed, migration, reservoirbjergart, fælde, forsegling, timing og bevarelse. Vælges undertemaet "reservoirbjergart", forklares og be-

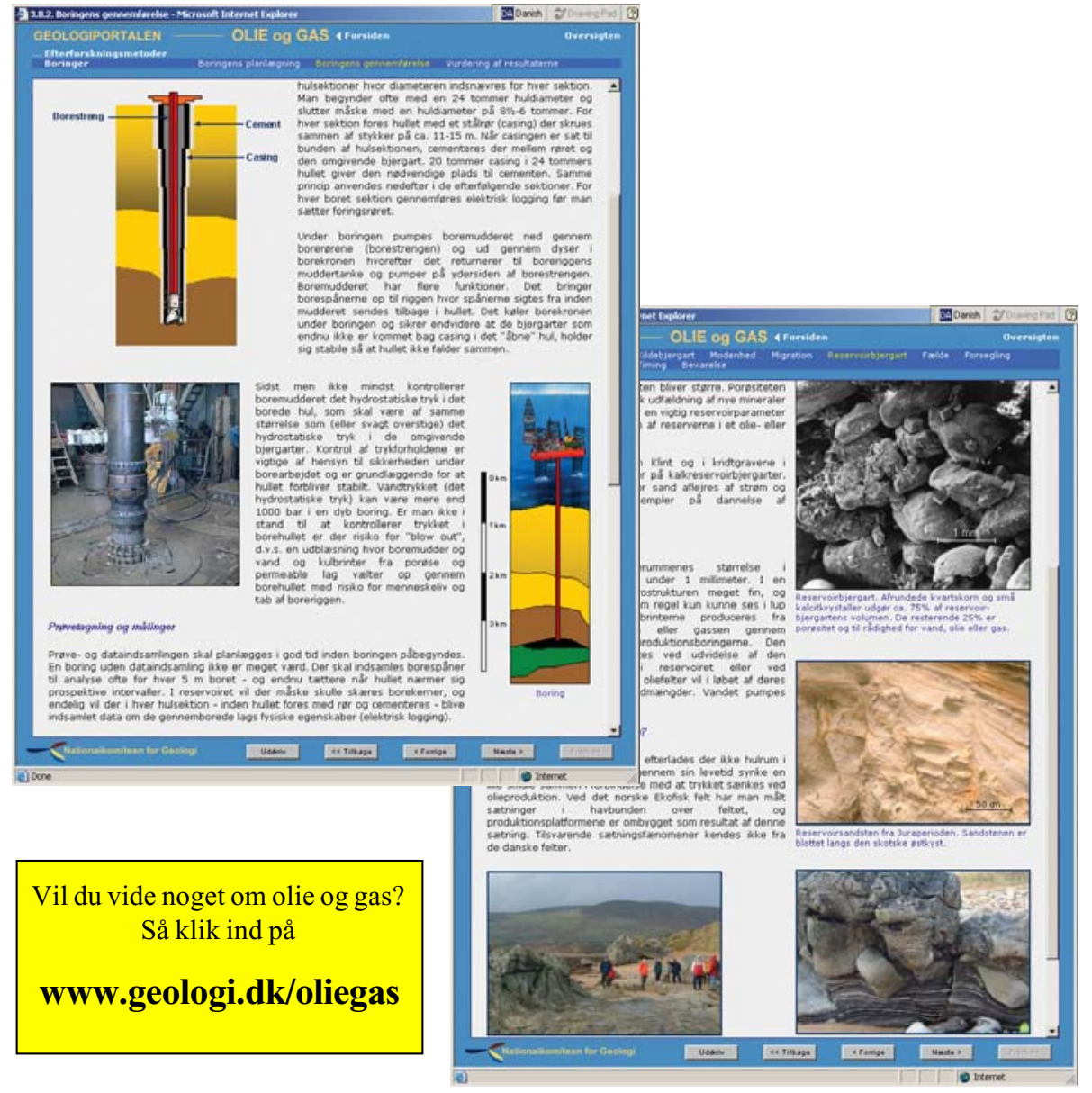

skrives vigtige begreber som porerum og mineralkorn - fremhævet med illustrative fotos af forskellige reservoirbjergarter. Et spørgsmål, som læseren sikkert vil stille efter at have læst om porøsiteter på op til $35 \%$, om eventuel sammenstyrtning besvares også.
Siden henvender sig til alle, som har lyst til at sætte sig ind i emnet olie og gas. Sidst, men ikke mindst er der en glimrende litteraturliste, hvor man kan hente inspiration samt en side med links til videre søgning. Så klik ind på www.geologi.dk/oliegas!

\section{Overrokkelse af DONGs hoederslegat}

\section{Af geolog Ulla V. Hjuler, GeologiskNyt}

Torsdag d. 22. april modtog professor John A. Korstgård DONGs hæderslegat på $100.000 \mathrm{kr}$. for sin forskning i geologien $\mathrm{i}$ den danske del af Nordsøen. Forskningen omfatter bl.a. dannelsen af olie- og gasførende lag i Siri-feltet samt større forståelse for strukturerne i området.; emner der naturligvis har stor interesse for DONG.

Finn Surlyk ved Geologisk Institut, Københavns Universitet modtog som den første legatet i 1999.

John Korstgård har været ansat på Aar- hus Universitet siden 1972, hvor han i perioden 1968-2002 har været på et væld af feltstudier. Desuden har han haft en erhvervskarriere ved siden af forskningen (bl.a. ansættelse inden for norsk olieindustri) og taget sig af forskellige administrative opgaver i universitetsregi - heriblandt som prodekan på Det Naturvidenskabelige Fakultet 2002-2006.

John Korstgård fik i øvrigt DGFs pris, Danmarks Geologipris, i 1994 for sin forskning inden for bassinanalyse og seismisk sekvensstratigrafisk analyse ved Aarhus Universitet.

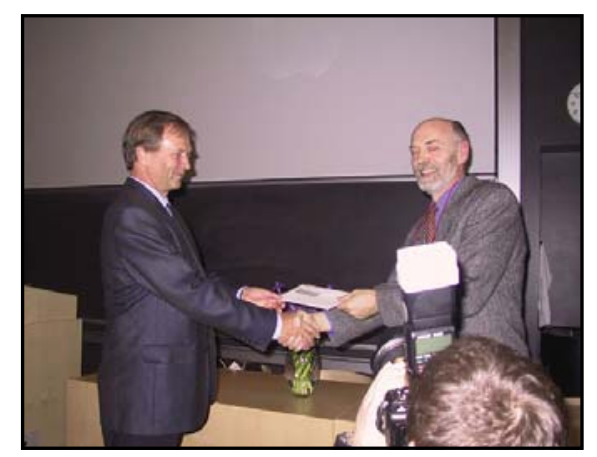

Overrakkelse af legatet. (Foto: Peter I. Petersen, DONG) 